\title{
THE CONTROL OF WAR PROFITS IN THE UNITED STATES AND CANADA.
}

\section{JAMES R. Witurow, JR. $†$}

One of the most significant legal, social and economic problems in wartime is the control of war profits. The United States and Canada have approached this problem in different ways. This country, after trying various other methods, is now relying upon the renegotiation of war contracts to recapture such profits after they have become excessive, while Canada has utilized a carefully planned procurement program to prevent exorbitant profits from ever arising. In view of the current discussions concerning the fairness and effectiveness of the American plan of renegotiating war contracts, a comparison with Canadian methods of controlling war profits and their results may well suggest revisions in the procedures which could be adopted in this country.

The laws regulating war profits in the United States have been profoundly influenced both by the situation in which the country found itself at the time it commenced to arm for war and by the methods used in World War I. In the summer of 1940 the collapse of France and the threatened invasion of England forced the United States to cxamine the state of its own defense preparations. As the gravity of the international situation became more and more apparent there was a demand for production of adequate war supplies at any cost. This emphasis on production is entirely logical when time is so important and when the Government's needs for munitions and supplies far outstrip industry's capacity to produce them. It was only after the expansion of war production was well under way that the Government began to reexamine the existing controls on costs and profits. Even today, after more than two years of war economy, there are agencies of the Government urging maximum war production regardless of cost, while Congressional Committees are criticizing excessive costs and the Price $\Lambda$ djustment Boards of the Army, Navy and Maritime Commission are renegotiating large war contracts in order to reduce profits on war business.

As far as the United States is concerned, the problem of war profits is an old one. Every war in which this country has been engaged has provided opportunities for profiteering and it appears that upon almost every occasion these opportunities have been taken advan-

†A.B, 1932, LL.B., 1935, Cornell University; member of the New York bar; contributor to various legal periodicals. 
tage of. ${ }^{1}$ On many occasions Congress has passed laws to meet the problem of war profiteering. It has authorized the fixing of prices; ${ }^{2}$ it has placed a percentage limitation on profits; ${ }^{3}$ it has recaptured high profits through excess profits taxes; ${ }^{\dagger}$ and finally in April, 1942, it established a procedure whereby all contracts involving large purchases of war materials may be renegotiated if the profits are excessive. ${ }^{3}$

\section{The Profit Motive in Wartine}

While the United States, in World IVar I and in this war, has attempted to prevent war profiteering, it has at the same time relied primarily upon the profit motive to insure the adequate production of munitions and supplies. Certainly most people have no quarrel with the idea of utilizing the profit motive as an incentive to war production. But it is questionable if they have faced the fundamental fact that profit can function as such an incentive only when those companies engaged in war production will receive relatively more profits than other companies and relatively more profits than they would have secured from non-war production. As long as this country relies on the profit notive to induce maximum production of war supplies, war profits are inevitable.

In wartime, of course, the emphasis upon low prices must give way to the necessity of securing the rapid delivery of a large volume of war supplies. For that reason the procurement officers of the armed forces are naturally more interested in the rapid delivery of munitions and supplies than in haggling over price or profits. In so far as the profit motive secures rapid delivery, procurement officers will be loath to see it eliminated. Because of its effect on production procurement, officers will certainly be more anxious to see the profit incentive retained than are the members of Congress. The latter are apt to be influenced both because public morale may suffer from scandals over excessive war profits and because it is popular to be opposed to war profits. In wartime it is natural to compare the sacrifices being

1. Hearings before Honse Commiltee on Military Affairs, on $H . R$. z and $H . R$. 5293. 74th Cong., 1st Sess. (1935) 590-98. See also Interim Rcport of House Committce on Naial Affairs, purstant to $H . R$. 162 (June 23, 1942) 44.

2. Emergency Price Control Act of 1942, Pub. Law No. 42r, 77th Cong., 2d Sess. (Jan. 30, 1942) ; Pub. Law No. 729, 77th Cong,, 2d Sess. (Oct. 2, 1942). (In World War I prices were fixed by a process of negotiation and agreement between Government and industry.) Note, American Economic Mobilization (1942) 55 HARv. L. REv. $427,482$.

3. $4^{8}$ STAT. 505 (1934), 34 U. S. C. A. \$ 496 (Supp. 194I); 49 Star. 1926 (1936), 34 U. S. C. A. \$ 406 (Supp. 1941) ; 49 STAT. $1908-99$ (I936), 46 U. S. C. A. \$ II55 (Supp. 1941); 53 STAT. 560 (1938), 34 U. S. C. A. $\$ 496$ (Supp. I941); 53 Stat. 59I (1939), 34 U. S. C. A. \$ 556 (Supp. 1941).

4. Revenue Acts of 1921, 194I, 1942.

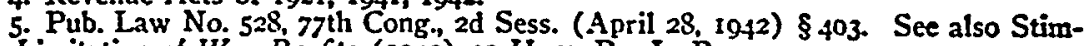
son, Limitotion of War Profits (1942) 91 U. OF PA. L. REv. 29. 
demanded of the public generally in the form of rationing and military service with the granting to producers of war materials of a proportional increased amount of income without realizing the effect that an undue curtailment of profits might have upon the production of munitions and supplies.

For over a hundred years the mere inequality of income has repeatedly been the foundation of political movements in this country, but the effect of such inequalities when produced by war are bound to be more objectionable. As a result it is to be expected that democratic governments will attempt to assert, and will assert, considerable control over war profits and perhaps even eliminate them entirely. Some controls are undoubtedly necessary because whenever the mobilization of a nation's resources to carry on a war is left to the laws of supply and demand high war profits necessarily emerge. Whether these controls can at the same time be effective guarantees of maximum production of war materials is open to serious question.

Since procurement officers have at the most only a secondary interest in low profits a government must either carefully plan and supervise the procurement of war supplies or else rely in a large measure upon specially designed taxes and such other devices as renegotiation of war contracts in order to control war profits. In some cases it may be expected that the controls used may actually interfere with the effective and efficient prosecution of the war. Perhaps from a Congressman's point of view the necessity of maintaining public morale by preventing discontent which might arise from high war profits is sufficient reason to justify some interference with war production. It is hard to believe, however, that such interference would be necessary if timely measures had been adapted to limit war profits.

Reliance upon the profit-making motive in the early stages of preparing for war is an effective way of securing production of war materials. At that time it acts as an incentive to convert from peacetime to war production, for it gives a premium to those changing from their routine production program to the manufacture of munitions and war supplies. After this conversion a company engaged in war work might well be compelled by some form of public control to continue in that type of work, without the presence of any economic incentive. The elimination of all economic incentive, however, might well result in a relaxation of efforts to increase production and to reduce costs unless some powerful substitutes were devised. ${ }^{\circ}$ From the experience of the United States in the last war and up to the present time in this war,

6. Hicks. Hicks \& Rostas, The Taxation of War Wealth (London, I941) contains a complete discussion of the economics of war profits as an incentive to production. 
there is little to justify the belief that the controls which have been advocated from time to time, would be effective in bringing about the efficient prosecution of the war. The Dominion of Canada, however, after initially approaching the problem of controlling war profits from a different point of view than that followed in the United States, now fcels it can afford to eliminate virtually all of the profit-making motive.

\section{Early American Efforts at Controlling War Profits}

The control of profits on defense or war contracts in the United States has a history going back at least to 1896 . In that year, after claims had been made that armor plate manufacturers were making exorbitant profits, the Naval Appropriations Act directed the Secretary of Navy to report both on the actual cost of producing armor plate and on a fair price for it. ${ }^{8}$ After the Secretary made his report in January, 1897,9 the Naval Appropriations Act of that year limited the cost of armor plate on any one contract to $\$ 300$ per long ton..$^{10}$

Since this beginning in 1897 many different legislative efforts have been made to control and limit war profits. The various methods of controlling war profits fall within four classes: First, the use of careful procurement procedures and cost controls; second, the limitation of profits by contractual or statutory provisions to a fixed percentage; third, the taxation of excess profits; and fourth, the renegotiation of war contracts.". From an economic point of view much can be said for the first and second alternatives as they tend to be more effective in keeping down the costs to the Government than the other two. It can readily be seen that none of these methods can guarantee the rapid delivery of high quality munitions and supplies at a low cost to the Government without their being carefully administered. Of these four methods, the renegotiation of war contracts is the newest; the statute controlling this procedure was passed in April, 1942.12 As a matter of fact, if the other three methods had been administered suc-

7. Under the Canadian Tax Act of 1942 the only incentive left to reduce costs if you are subject to the excess profits taxes depends on whether the $20 \%$ return of excess profits taxes after the war can be considered an effective incentive to operate at the maximum efficient capacity. For details of the Act see 92 Canadian House of Com:mons Debates 3901 it scq. (June 23, 1942).

8. 29 STAT. 379 (1806). As early as I886 the Navy was directed to buy Americanmade armor if it could be secured at a "reasonable price". 24 STAT. 215 (I886).

9. 29 Cong. Rrc. 481 (1897).

10. 29 STAт. 665 (1897).

11. Note, War-time Contracts and Control in Equity of "Inordinate" Profit (I941) 9 GEO. WAsn. L. REv. 603. This article urges the Equity Courts to solve this problem by recognizing a fiduciary relationship. This theory was repudiated by the majority in United States v. Bethlehem Steel Corp., 315 U. S. 289 (1942), but was adopted in Mrr. Justice Frankfurter's dissent (Id. at 325, 326). See also its denial in an analogous situation in United States v. Union Pacific R. R. Co., 98 U. S. 569 (1878).

12. See note 5 supra. 
cessfully there would have been no necessity for a law providing for the renogiation of war contracts.

One of the factors which makes it so difficult to deal with the problem of war profits is the conflicting idea of just how to measure the extent of war profits. Most government representatives insist that the existence of war profits should be measured before taxes, while most businessmen maintain that there are never any profits until all existing taxes have been paid. The Congress, of course, always has the last word about federal taxes especially when its aim is to curtail profits by taxes. This controversy has come out into the open in renegotiations of war profits with Price Adjustment Boards as these Boards generally take the conventional government approach.18

The way in which profits on sales to the government are normally controlled is by the procurement methods employed. In peacetime most products are purchased by means of invitations for sealed bids. ${ }^{14}$ This is a method which can only produce the lowest cost to the Government when the capacity to produce (or a willingness to convert facilities) exceeds the Government's demands. Even in peacetime, military authorities have complained that procurement by means of competitive bidding caused unnecessary delays. ${ }^{18}$ As a result a series of laws going back to 1901 permit the armed forces to make purchases without advertising for sealed bids "in cases of emergencies". 18 The art of procuring the supplies to equip and maintain a modern army in wartime is entirely different from peacetime procurement, because- for most items there is an inadequate supply to meet the Government's demand. In addition there is a premium upon rapid delivery, upon continued increasing capacity and upon accurate adherence.to exacting specifications. Under these conditions it is not surprising that different procurement methods are employed.

Most of this country's wartime procurement methods originated from the experience had in World War $I$. After war was declared in April, 1917, there was a period of initial confusion when both the Army and Navy tried to use their peacetime procurement methods. The various purchasing agents would advertise for sealed bids with

13. War Dept. Principles, Policy and Procedures to be followed in Renegotiation (Price Adjustment Board, August 10, 1942).

14. Rev. Stat. \$ 3709 (1875), 4I U. S. C. A. \$ 5 (1940); 3I Stat. 905 (1902), 10 U. S. C. A. \$1201 (1940).

15. N. Y. Times, January 21, 1940, p. 17, col 3.

16. 3I Stat. 905 (I901), 10 U. S. C. A. § IzoI (1940). See also 23 Stat. Iro (1884), 10 U. S. C. A. $\$ 1364$ (1940). In addition the purchase of certain items has been permitted without advertisement. 20 STAT. 253 (1878); 27 STAT. 485 (1893); 28 Srat. 658 (1895); 34 STAT. 258 (1906); 34 STAT. 1193 (1907); 35 STAT. I25 (1908); 4r Stat. 967 (1920); 49 Stat. 1277 (1936); 53 Stat. 591 (ig39); 53 Stat. 1000 (1939); 53 Stat. 1042 (1939). 
the result that purchases were being made by numerous separate agencies who actually competed with each other in the securing of supplies. ${ }^{17}$ The result was an artificially enhanced demand which raised prices and increased profits on many war contracts. Steps were soon taken to alleviate much of this confusion by unifying the procurement of supplies. The Council of National Defense, composed of six cabinet officers, set up three committees to deal with the problem. ${ }^{18}$ The most important of these was the General Munitions Board composed of 24 representatives of the Army, Navy and the public. This Board supervised most of the military and naval purchases. ${ }^{10}$ The other two had more restricted authority. Thus, the Committee on Supplies dealt with the procurement of clothing, equipment and subsistence, while the Committee on Raw Materials, Minerals and Metals allocated these necessities. ${ }^{20}$ These three committees were supplanted in July, 1917 , by the War Industries Board which was given broad power to control industry. This Board largely straightened out the problem of purchasing and producing war materials. ${ }^{21}$

Even though the procurement of war supplies was controlled by one central body it was found that the procurement of munitions and supplies by advertising for competitive bids had to be discontinued. At best it was a slow and cumbersome method and, in addition, as labor and production costs spiralled higher and higher many companies were unwilling to subnit bids on a fixed-price basis. The companies which refused to bid pointed out that the government required bids to be submitted on a fixed-price basis, which was sheer suicide in the face of rapidly rising costs. The dangers to the producers under fixed-price contracts came to be recognized by the War Department. ${ }^{22}$ As a result, cost-plus contracts were devised to protect industry and they soon largely supplanted fixed-price contracts. ${ }^{23}$ These cost-plus contracts were of two types: cost-plus-a-percentage-of-cost and cost-plus-a-fixedfee. The possibilities of an unscrupulous company abusing the cost-

17. Graske, The Law of Governyext Defense Contracts (1941) 6-8. T. N. E. C. Alonograph 19, Government Purchasing (1940) 43 ct seq.

18. GraskF, op. cit. supra note 17 , at 8-9. The National Defense Council was set up under 39 Stat. 166 (1916) with authority to set up subordinate boards and agencies.

19. Garrett, Government Contrnl over Prices, War Industries Board Price Bulletin No. 3 (1920) 198.

20. Ciarkson, Industrial Auerica in the Wortd War (1923) 35.

21. GRASKe, op. cit. stpra note 17, at 10-12.

22. Report of Chicf of Construction Dizision, IVAR Departuent Anvual Report (1919) 4I47, where it is stated, "Obviously no sane man would bid on a lump-sum contract under such conditions, unless perchance he should treat the matter as a pure gamble and include an excessive margin in his proposal for unforeseen contingencies." Quoted with approval in United States v. Bethlehem Steel Co., 315 U. S. 289, 302 (1942).

23. Graske, op. cit. supra note 17 , at 17 , 18 . 
plus-a-percentage-of-cost contract soon led to its disfavor. ${ }^{24}$ During this war the use of this type of contract is prohibited by law. ${ }^{28}$

The cost-plus-a-fixed-fee contract was quite widely used in the last war. It was soon realized, however, that this contract was not a panacea to the problem of low-cost procurement of supplies. Its chief drawback was that it failed to provide any incentive to the producer to increase the efficiency of operation either by shortening the production time, by saving vital materials, or by reducing those costs to be paid by the Government. ${ }^{28}$ This lack of incentive led to a variation of the cost-plus-a-fixed-fee contract by which a bonus was given for savings in cost. While this form of contract included an incentive to reduce costs it also encouraged unscrupulous manufacturers artificially to inflate their estimates of cost. ${ }^{27}$ The large profits of some companies under this type of contract was severely criticized after the war. ${ }^{28}$ In fact it was a controversy over such a bonus contract which was before the Supreme Court in the recent Bethlehem Steel case. ${ }^{20}$

During the last war, both the Army and the Navy tried to limit profits on contracts. Thus, the Navy adopted a policy of trying to have its contracts allow no more than 10 per cent. of the actual cost as profits. ${ }^{30}$ The War Department placed a ceiling of 10 per cent. profit on cost-plus contracts for the construction of cantonments. ${ }^{21}$ The percentage decreased as the size of the project increased, the lower limit being 5 per cent. These limitations were not imposed by statute and no effort was made to recapture profits in excess of these amounts.

Another approach to the control of war profits was the fixing of prices on the sale of certain commodities. A study of what was a "fair . and just price" for such commodities was begun under the General Munitions Board early in the war and prices were fixed as a result. Whenever a flat price could not be agreed upon, the Board decided to authorize the payment of actual-cost plus a ro per cent. profit in order to hasten deliveries. ${ }^{32}$ When this function was taken over by the War

24. Graske, op. cit. supra note 17, at 18; Report to tile Attorney General on THE AIRCRAFT INQUiRY (1918) 134, reprinted as Appendix A, 57 CoNG. REC. 883-914 at 906 (1918); Expenditures in the War Department-Camps, H. R. REP. No. 816, 66th Cong, 2d Sess. (1918) 49-53.

25. 54 Stat. 676 (1940); 54 Stat. 712 (1940).

26. Hearings before House Commilfee on Afilitary Affairs on $H . R .3$ and $H . R$. 5293, 74th Cong, Ist Sess. (r935), especially at 604 et seq.; T. N. E. C. Monograph 19, Government Purchasing (1940) 50-54; GRAsKe, op. cit. supra note 17, at 121 et seq.

27. Cf. United States y. Bethlehem Steel Corp., 315 U. S. 289 (1942).

28. Such a contract is permitted under a ruling by the Comptroller General. GRASKE, op. cit. supra note 17 , at 135-136.

29. United States v. Bethlehem Steel Corp., 315 U. S. 289 (1942). $147-8$.

30. REP. SEC'y NAVY (1917) 33; Id. (1918) 685; Id. (1919) 572-576; Id. (1920)

31. REp. SEC'y WAR (1917) Vol. i, p. 28; Id. (1918) Vol. I, p. 1319; Id. (1919) 4138-42. See also Croweir, Governuent WAr Contracts (1920) 85.

32. T. N. E. C. Afonograph 19. Goz'cmment Purchasing (1940) 51. 
Industries Board, it fixed prices through its Price Fixing Committee. In general, these prices were fixed at fairly high levels so that efficient producers were able to make large profits. ${ }^{33}$

It seems that the National Defense Act of 1916 could have been used to control profits in World War I.34 Under this Act the President, in case of war, had the power to purchase munitions and supplies provided the compensation to be paid for the "products or material, or as rental for use of any manufacturing plant while used by the United States, shall be fair and just." The ultimate question of the fairness of prices under this statute could be taken to the courts if the manufacturer was dissatisfied. This power was rarely exercised. ${ }^{85}$ The War Industries Board, purporting to act under this Act and other statutes, ${ }^{36}$ did enter into agreements with industries which fixed profits on some items. ${ }^{87}$ In one or two instances the courts entertained suits by the United States under these statutes and the industry agreements to recover excessive profits. ${ }^{\text {s8 }}$

The control of war profits in World War I was largely left, however, to the tax laws. President Wilson in a joint session of Congress on May 27, 1918, urged a new tax bill using these words:

"The profiteering that cannot be got at by the restraints of conscience and love of country can be got at by Taxation. There is such profiteering now and the information with regard to it is available and indisputable." 30

Congress immediately began to investigate profiteering. Early in June a resolution proposed by Senator Borah directed the Treasury to submit information on profiteering, including a list of all corporations which earned in excess of 15 per cent. on their capital stock for the year 1917 , and the 1916 earnings for the same companies. ${ }^{10}$ On June Io, a second Borah resolution was passed, directing the Federal Trade Commission to report on profiteering. ${ }^{41}$ The Commission concluded in its report on June 29, 1918, that profiteering existed in many lines. ${ }^{42}$ Subsequently the Commission submitted specific reports on such industries as the copper industry. ${ }^{43}$ In July the

33. Id. at 5T, 52.

34. 39 StaT. 213 (1916), 50 U. S. C. A. $\$ 80$ (1928).

35. GRASKE, op. cit. supra note 17, at 19.

36. 39 Stat. 649 (1916).

37. Note, American Economic Mfobilization (1942) 55 HARv. L. Rev. 427, 482.

38. United States v. Powers, 274 Fed. 131 (W. D. Mich. 1921); United States v. Gordin, 287 Fed. 565 (S. D. Ohio, 1922).

39. 56 CoNG. Rec. 7115 (1918).

40. Id. at 723r, 7420.

41. Id. at 7558 .

42. Profitecring, S. Doc. No. 248, 56 CoNc. Rec. 8458-62 (1918). See also Hearings Before House Commiltee on Mfilitary Affairs on $H . R .3$ and $H . R .5293,74^{\text {th }}$ Cong, ist Sess. (1935) 604 et seq.

43. Cost Reports of the Federal Trade Commission-Copper, June 30, 1919. 
Treasury submitted its report showing a high percentage of profits and large salaries. ${ }^{14}$ After making these factual inquiries into the extent of war profiteering Congress followed President Wilson's program. Higher taxes were enacted and the government relied primarily upon the excess profits taxes to control war profits. These taxes culminated in a levy of 80 per cent. ${ }^{45}$.

\section{America Begins to Plan After World War I}

The methods employed during World War I resulted in much criticism. Although many of the reports on the profits by producers of munitions and war supplies may properly be dismissed as either witch-hunts or misguided zeal, certainly there is adequate ground for concluding that the problem of controlling war profits was not solved." This situation led to the passage of the National Defense Act of 1920, which directed the Assistant Secretary of War to make "adequate provision for the mobilization of material and industrial organizations essential to wartime needs". ${ }^{47}$ This was the beginning of planning for procurement for the present war. Since that time the War Department has been working on what it characterized as the development of

". . . an adequate, coordinated and integrated program of wartime procurement adapted to the American system of government and industry, which will function effectively in case of war." 1s

In many respects this planning was quite thorough. A War Policies Commission was set up to study the last war and to make recommendations concerning changes in procurement procedure. ${ }^{10}$ But most of this peacetime planning was directed at providing for the orderly procurement of war supplies. It was designed to reduce the possibilities of government procurement officers forcing up prices by competing with each other. ${ }^{50}$ While all of this planning would provide for the orderly procurement of war supplies, little of it was devoted specifically to the more difficult job of designing methods to insure reasonable prices and to prevent excessive war profits. The War Policies Commission made one contribution in this direction by recommending that a constitutional amendment be passed to eliminate all doubt as to the power of Congress to prevent war profiteering. ${ }^{51}$ It also recommended that in time of war

4456 Cong. REC 8671 (1918).

45. 39 Stat. 1000 (1917); 40 Stat. 302 (1917); 42 Stat. 271 (1921).

46. United States v. Bethlehem Steel Corp., 315 U. S. 289 (1942).

47. 4I Stat. 764,765 (1920).

48. REP. SEC'Y WAR (1938) 27. (1931).

49. Report of War Policies Commission, H. R. Doc. No. 163, 72d Cong, Ist Sess.

50. T. N. E. C: Monograph 19, Government Purchasing (1940) 54-63.

51. Report of War Policies Commission, H. R. Doc No. 264, 72d Cong, ist Sess. (1932) 3; REP. SEC'Y WAR (1932) 303 . 
individuals and corporations be taxed 95 per cent. of all the income above the previous 3 year average.

One concrete result of this planning was the establishment of the Army and Navy Munitions Board to coordinate procurement by these two services. ${ }^{52}$. Another result was the decision to abandon competitive bidding for the procurement of military supplies in time of war. ${ }^{.8}$ General Douglas MacArthur, former Chief of Staff, stated before the War Policies Commission: "We plan to base wartime procurement upon allocation rather than upon the competitive-bidding standard prescribed in peace".54 He further contended that "Prices will be determined by negotiation, controlled by the knowledge obtained in peacetime planning, of the items that make up costs and by all information that can be collected by the government." ss Another result was the establishment of the Army Industrial College to train military men in the procurement field. ${ }^{\text {se }}$

It is only natural that the emphasis on efficiency and speed in wartime procurement necessitates laying aside, at least temporarily, the practice of securing competitive bids. Congress has, since the beginning of the war, given broad authority to negotiate contracts without advertising and without competitive bids. ${ }^{57}$ If this practice of negotiating contracts is to take the place of competitive bidding, then a careful system of cost accounting and price determination is necessary to furnish some check on inflationary tendencies, which are controlled in peacetime, in part at least, by competitive bidding. As competitive bids are asked on only a small portion of the Government's current purchases some attention is necessary to see what has been developed in its place.

Despite this country's experience in the last war, no revolutionary changes have been made in the procurement methods now in use. In fact there is a similarity in the development of current procurement techniques with the evolution which took place in 1917 and 1918. Generally speaking the same types of contracts are in use today which were found to be ineffective in controlling profits in World War I. Thus, at the present time, there are two principal types of negotiated contracts, the fixed-price contract and the cost-plus-a-fixed-fee contract. While the fixed-price contract is the favorite form of contract, cost-plus-a-

52. This Board was created by joint order of the Secretaries of War and the Navy in 1922. See REP. SEC'y W

53. Repart of the IVar Policies Commission, H. R. Doc. No. 163, 72d Cong, rst Sess. (1931) 363; REP. SEC'Y WAR (1932) 304-

54. Report of the War Policies Commission, loc. cit. supra note 53, at 363 .

55. Id. at 364 See also H. R. Doc. No. 264, $72 d$ Cong., Ist Sess. (1932) 3.

56. REP. SEC'Y W $W_{A R}$ (1931) 26 ; Id. (1934) 28 ; Id. (1939) 20.

57. 54 Stat. 714 (1940); 54 Stat. 676 (1940); 54 STat. 297 (1940); 54 Stat. 377 (1940); 54 Stat. 875 (1940); 54 Stat. 600 (1940); Pub. Law No. 139, 77th Cong., ist Sess. (June 30, 194I). 
fixed-fee contracts are employed in a great many situations such as where the source of production is limited and where the jobs are large jobs and speed is essential. The fixed-price contract, since it guarantees to the manufacturer as his profit the difference between the fixed-price and his actual cost, contains an incentive to the manufacturer to keep his cost of production as low as possible. In face of rising prices, and other costs, it has been necessary to insert in fixed-price contracts, escalator clauses which provide for reimbursing the contractor in the event of substantial increases in the price of materials or in the cost of labor. Since, under the cost-plus-a-fixed-fee contract, the Government will reimburse the manufacturer for most items of direct cost there is no pressure upon the manufacturer to keep down costs. The only difference from the last war in the types of contracts employed is the elimination of the cost-plus-a-percentage contract.

The extensive use of the cost-plus-a-fixed-fee contracts, in spite of the disappointing experience the United States had with them in the last war, is surprising. This is especially true because the experience of the British Government with the use of cost-plus contracts in this war was quite similar to America's experience in the last war. ${ }^{\text {bo }}$ Moreover, Congressional Committees have recommended that a study be made of alternate methods for contracts to displace the cost-plus-afixed-fee contract. ${ }^{50}$ These Committees seem to favor fixed-price contracts with escalator clauses whereby the agreed price is changed in definite relation to changes in wage rates and basic commodity prices. The War Department in using these cost-plus contracts has taken the position that they were necessary to avoid serious delays. ${ }^{.0}$

During the last war, one way in which the costs to the Government were increased was by the existence of contingent fee brokers. ${ }^{\text {a }}$ This increase in cost to the Government has been lessened during the

58. Report of the Seiect Committee on National Expenditures (London, 1941). This Committee concluded that the best type of contract was the fixed-price contract, and that the cost-plus-a-percentage-of-cost was the worst. This report comes out strongly for the fixed-price contracts with the price based upon technical costing studies. The Committee, in reference to the problem of controlling war profits, concluded that profits should be related to amount of capital employcd and that some degree of uniformity was desirable in so far as practicable. The Committee favored a fred rate to cover each industry, with some flexibility retained to offer special incen-
tives for special effort.

59. Interim Report. of House Committee on Military Affairs; pursuant to $H . R$. 162, 77th Cong, Ist Sess. (194I) 14-16. See also Interim Report of House Committee on Naval Affairs, pursuant to H. R. 162, 77th Cong., Ist Sess. (June 23, 1942) 5, 43.

60. REP. SEC'Y IVAR (I94I) 29 . "In order to avoid serious delays that would be involved by use of lump-sum contracts, resort has been made to the use of the cost-plusa-fixed-fee form of contract in 2 number of cases. . " Such contracts could be used only if authorized by the Assistant Secretary of War.

REP. SEC'Y NAVY (I94I) 39 says the Navy has used competitive bids except when their use "would be detrimental to the interests of the Government".

61. Crowell, Governuent War Contracts (1920) 22. 
present war by covenants in contracts against contingent broker fees. ${ }^{.2}$ There is also pending in Congress, a bill passed by the House ${ }^{68}$ and now in committee in the Senate, prohibiting the payment of contingent fees to contract brokers. The Senate committee has revised this bill so as to permit some contingent fees provided that the purchasing officer finds that those fees are not "in excess of the amount determined to be reasonable". ${ }^{\circ 4}$ The Senate bill also provides for a withholding of payments to the seller if such fees are determined to be unreasonable or excessive.

\section{Profit Limitation to a Statutory Percentage}

While no significant changes have been made in procurement methods employed at the close of World War I, some statutes have been passed to control war profits by statutory limitations on profits. The first such law was passed in 1934. At that time President Roosevelt was asking Congress to appropriate money to build up the Navy to Treaty strength. ${ }^{\text {os }}$ This request brought out a storm of criticism. Senator Borah made his famous "Take the Profit out of War" speech "o and Senator Nye began work on his "Munitions Investigation"..2 The country was deluged with the stories of exorbitant profits made in World War I. It is not surprising that when Congress did authorize the naval construction program in 1934, the Vinson Act limited profits to be realized by the builders of the new warships. ${ }^{\text {s }}$ This law limited the profits on these naval construction contracts to ro per cent. of the contract price, and it required each contract to contain a provision binding the contractor to pay back to the Treasury all profit "in excess of Io per centum of the total contract price." The books of contractors were to be open to inspection and audit. The method of ascertaining the amount of "excess profit" was to be the subject of a joint order by the Secretaries of the Treasury and Navy. ${ }^{\circ 8}$

62. 2 C. C. H. War Law Serv. II $22,601.52,22,603.33,22,610.24,22,628.20$ (194a).

63. H. R. 7304, 77th Cong., 2d Sess, passed by the House July 20, 19p.

64. H. R. 7304, 7jth Cong, 2d Sess, as amended August 12, 1942.

65. 78 CoNG. Rec. 1601 (1934).

66. 78 CoNG. Rec. 3688 et seq. (1934). Senator Borah's theme was (p. 3689): "It is not alone that they [munitions makers] are engaged even at a reasonable profit in an enterprise which would be a matter in itself sufficiently serious for consideration, but the exorbitant profits and gains which they make in furnishing instruments to maim, to destroy their fellow men, is something almost unbelievable."

67. Hearings before a Special Senate Committee to investigate the Munitions industry began on Sept. 4, I934, pursuant to $S$. Res. 206, 73d Cong. (I934).

68. 48 Stat. 505 (1934), 34 U. S. C. A. $\$ \S 496-497$ (Supp. I941).

69. The original order was issued in May, 1934. 26 Code of Federal Regulations $8 \$ 5.0$ to 5.20 ; Treasury Decision 4434 , amended January 6,1937, by T. D. 4723,2 F R. 43, and again September 19, 1938, T. D. 486r, 3 F. R. 2279. It was in the amendment that there appeared the first positive reference to unreasonable compensation of executives and directors. 
In 1936 to make the Vinson Act more workable it was amended. ${ }^{70}$ One of the new provisions permitted the offsetting of losses on one contract against profits on another. This was accomplished by extending the Io per cent. profit limitation to the aggregate contract prices of all contracts completed during each taxable year. In addition the amendment permitted the offsetting of net losses for one taxable year against net profits during the succeeding taxable year. In the same year the Merchant Marine Act extended this 10 per cent. limitation on profits to ships built for the Maritime Commission. ${ }^{11}$

The Merchant Marine Act was the first of these profit limitation statutes which contained any specific provisions concerning the meaning of profit and allowable costs. While the Act directed the Commission to determine what constituted profit, it did have specific provisions as to certain matters. For example it provided "that in computing such profits no salary of more than $\$ 25,000$ per year to any individual shall be considered as part of the cost of building such ship." It also directed the Commission to "scrutinize construction costs, and overhead expenses to determine" whether they were "fair, just and not in excess of a reasonable market price".

Prior to 1939 the limitation of profits had not been extended to Army contracts. In that year a limitation was put on the profits derived from military aircraft. ${ }^{72}$ The same statute amended the Vinson Act so that the ro per cent. limitation on profits applied only to naval vessels and provided for a maximum of 12 per cent. profit on contracts for military or naval aircraft. Later in 1939 the Navy was given power to enter into defense contracts on a cost-plus-a-fixed-fee basis with the fee limited to ro per cent. of the cost of the contract exclusive of the fixed fee. ${ }^{73}$ All of these statutes were actually peacetime procurement laws. The country was not yet preparing for war.

The Act of June 28, 1940, coming as it did after the fall of the Low Countries and France, is really the beginning of the war legislation in the United States. ${ }^{7 t}$ This Act authorized the negotiation of contracts for the construction and repair of naval aircraft and vessels without competitive bids and it reduced the profit limitation in the Vinson Act for their procurement to 8 per cent. of the total contract price or 8.7 per cent. of the cost of performing the contract. Provision was also made to extend the provisions of this Act to subcontractors, and to permit the Secretary of the Navy to take over and operate any necessary plant or facility wherever its use and operation could not be guar-

70. 49 STAT. 1926 (1936), 34 U. S. C. A. \$ 496 (Supp. 1941).

71. 49 StAT. 1998-99 (1936), 46 U. S. C. A. \$ II55 (b) (1940).

72. 53 Stat. 560 (1939), 34 U. S. C. A. $\$ 496$ (I940).

73. 53 Stat. 591 (1939).

74. 54 Stat. 676 (1940); 4I U. S. C. A. note preceding \& I (Supp. 194r). 
anteed by a contract with its owners. While this $A c t$ authorized the use of the cost-plus-a-fixed-fee type of contract it prohibited the use of cost-plus-a-percentage-of-cost contracts. The War Department was given power to negotiate similar contracts in July, 1940.75 In the case of the War Department the amounts of the fees, however, on most of the War Department's cost-plus contracts were not limited until March, 1942.70 Late in 1940, however, the fees on public works on Army camps were restricted to 6 per cent. ${ }^{77}$ In March, 1942, the fees were set at 7 per centum of the estimated reimbursable cost on most War Department contracts, ${ }^{78}$ and in June the fees on work at Army camps were again limited to 6 per cent. ${ }^{79}$ The law of July 2, 1940,80 did prohibit the War Department from entering into cost-plus-a-percentage-ofcost contracts.

\section{Profit Limitation by Excess Profits Taxes}

The days of profit control by a percentage limitation were numbered. On September 9, 1940, the operation of the profit limitation features of the Act of June 28, 1940, was restricted to contracts for the construction of naval vessels. ${ }^{81}$ This in effect suspended its operation on contracts for naval and military aircraft. In October, 1940, the profit limitation statutes applicable to all military and naval and most merchant marine contracts and subcontracts were suspended by the Second Revenue Act of 1940, whenever the contracts or subcontracts were subject to the excess profits tax. ${ }^{82}$ One effect of this Act was to suspend certain Treasury Decisions relating to cost determinations on contracts for naval vessels and military and naval aircraft. ${ }^{83}$ These specific profit limitations were suspended in the hope of securing a more equitable and uniform handling of all war contracts. ${ }^{84}$ These limitations may be revived, however, by Presidential proclamation or a joint resolution of the two Houses of Congress.

With the suspension of these profit limitation provisions, the Revenue Acts became the chief limitation on war profits. These Acts have successively increased the excess profit tax rates. The Second

75. 54 Stat. 712-714 (1940). See also 41 U. S. C. A. note preceding \$ I (Supp. 1941), and 54 STAT. 883 (1940).

76. Pub. Law No. 507, 77th Cong., 2d Sess. (March 27, 1942).

77. 54 Stat. 873; 54 Stat. 968 (1940).

7S. Pub. Law No. 507, 77th Cong., 2d Sess. (Mrarch 27, 1942).

79. Pub. Law No. 5So, 77 th Cong, 2 d Sess. (June 5, 1942).

80. 54 STAT. 713 (I940), 41 U. S. C. A. note preceding \$ I (Supp. 1941).

81. 54 STAT. 883 (1940), 4 I U. S. C. A. note preceding \$ I (Supp. 1941).

82. 54 StAT. 1003 (1940), 34 U. S. C. A. \$ $496 a$ (Supp. 1941).

83. T. D. 5034, 6 FED. REG. 669 (194I) suspended T. D. 4906,4909 and 5000.

84. Refort of IVays and Mfeans Consittee ox Second Retexte Act of 1940, $76 t_{1}$ Cong, 3d Sess. (1940). It stated that uniformity in treatment would be achieved for all abnormal profits by the suspension of the Vinson-Trammell Act. 
Revenue Act of 1940 operated to tax 25 to 50 per cent. of all earnings in excess of peacetime earnings. ${ }^{83}$ Later, by the Revenue Act of 1941, these limitations were increased by taxing 35 to 60 per cent. ${ }^{88}$ of such added earnings. The 1942 Revenue $A c t$ has increascd these taxes to 90 per cent. with a 10 per cent. post war credit. ${ }^{87}$ The other limitation which now affects war contracts is the Renogiation Statute. ${ }^{83}$

Although the excess profits tax laws were intended to supersede the laws limiting profits to a specific percentage, in 1942 profit limitation provisions began to reappear in various statutes. The Second War Powers Act ${ }^{89}$ in March, 1942, limited the profits on all fixed-fee contracts of the War Department to 7 per cent. of the estimated cost of the contract exclusive of the fee to be paid to the contractor. Fixed-fee contracts of the Navy negotiated under this Act are subject to the same limitation. In June, 1942, a limitation of profit to 6 per cent. of the estimated cost on fixed-fee contracts for public works at military posts was imposed. 90

\section{Profit Limitation by Renegotiation of Contracts}

Nineteen forty-two witnessed the birth of a new method of controlling war profits. Evidence had been accumulating late in I94I that neither high excess profits taxes nor the limitation of profits to a specific percentage had not been effective in eliminating exorbitant war profits. As a result late in $194 \mathrm{I}$ attention began to be turned to the renegotiation of war contracts as a method of controlling war profits. At first these activities were purely voluntary. The First War Powers Act had authorized the President to allow any department to renegotiate existing and future war contracts whenever the department.believed it would facilitate the prosecution of the war. ${ }^{21}$ While this law authorized the renegotiation of war contracts, it did not authorize such renegotiation for the purpose of curtailing war profits. In December, 1941, pursuant to this Act, President Roosevelt authorized the Army, Navy and Maritime Commission to renegotiate their contracts. ${ }^{92}$

During the winter and spring of 1942 Congress and Congressional Committees began to examine the possibilities of controlling war profits by renegotiation. Thus, the House Naval Affairs Committee in January, 1942, recommended that contracts showing excessive profits be

85. 2d Revenue Act of 1940, 54 Stat. 975, 26 U. S. C. A. \$710 (Supp. 1941).

86. Revenue Act of 1941, 55 STAT. 687, 26 U. S. C. A. \$201 (Supp. 1941).

87. Revenue Act of r942, Title II.

88. Pub. Law No. 528, 77th Cong., 2d Sess. (April 28, 1942) 8403 .

89. Pub. Law No. 50\%, 77th Cong., 2d Sess. (March 27, 1942).

90. Pub. Law No. 580, 77 th Cong., $2 d$ Sess. (June 5, 1942).

91. Pub. Law No. 354, 77th Cong., 1st Sess. (December 18, 1941).

92. Executive Order 900I (Dec. 27, 1941), 6 FEd. REG. 6787 (Dec 30, 1941). 
renegotiated to reduce the huge profits being realized on many of them.93

While this trend toward the compulsory renegotiation of war contracts was developing, the Supreme Court of the United States handed down its decision in the Bethlehem Steel case. ${ }^{94}$ In that case the Court had before it the question of profits which arose out of the first World War. After sustaining the right of the Bethlehem Steel Corporation to the bonus for savings called for in its cost-plus contract, Mr. Justice Black pointed out that Congress had taken various steps to regulate and curtail war profits. The Supreme Court, sitting in equity, had no power, said the Justice, to vary the provisions of a contract which provided for large war profits. Said Mr. Justice Black : ${ }^{\text {os }}$

"If the executive is in need of additional laws by which to protect the nation against war profiteering the Constitution has given to Congress, not to this court, the power to make them."

Soon after this decision was handed down Congress in the Second War Powers Act began to lay the ground work for the renegotiation of contracts. ${ }^{\circ 0}$ Pursuant to that Act the President, on April 8, 1942, issued an order designating officers in the IVPB, the Army, Navy, Treasury, RFC and the Maritime Commission to inspect the books and plants of all companies with a large volume of war contracts to determine whether they had accumulated unreasonable profits. ${ }^{97}$ Neither the Second War Powers Act nor the President's order gave these officers any power to bring about a reduction in war profits. Under this order, the Army, Navy and Maritime Commission established cost analysis sections and Price $\Lambda$ djustment Boards. ${ }^{88}$ These cost analysis sections were to conduct general surveys of profits and costs of the holders of war contracts, and to act as fact finding agencies for the Price Adjustment Boards. These Boards were to assist the various departments in securing voluntary adjustments as refunds in instances where costs and profits were excessive for any reason. Although renegotiation was on a voluntary basis, ${ }^{99}$ a large volume of refunds were made. ${ }^{100}$

93. Report of House Conarittee on Naval Affairs plisuant to H. $R$ i6z (Jan. 20, 1942) 104.

94. United States v. Bethlehem Stel Corp., 315 U. S. 289 (1942). See Note (1942) 51 YALE L. J. 855 .

95. 315 U. S. 309.

95. Pub. Law No. 507, 77th Cong., 2d Sess. (March 27; 1942).

97. Exccutive Order 9127 (April IO, 1942), 7 FED. REG. 2753 (April 11, 1942).

93. IV. P. B. Release No. 1017 (April 30, 1942); O. WV. I. Release No. 163 (July 24. 1942).

99. Supplemental Report, House Committce on Nazal Affairs, purswant to $H$. $R$. 162 (July 22. 1942) 26-32, reported refunds of $\$ 533$, \$958, \$\$8\%. Preliminary Report House $N$ itial Atfairs Committee picrsuant to $H$. $R$. 162 (Jan. 20, 1942) 101-1a4.

10n. Priliminary Report of House Commitice on Naz'al Affairs purswant to $H . \Omega$ $16=$ (June 23. 1942) 11 ; Id. (July 22, 1942) 26-32. 
The whole question of additional controls over war profits was precipitated by the introduction of the Smith-Vinson Bill. The bill was a hybrid measure coupling a 6 per cent. limitation of profits on war contracts, with a relaxation of the IVages and Hours Law, so as to terminate overtime payments below a 48 -hour week. ${ }^{101}$ When hearings on the Smith-Vinson Bill were in progress during March, I942, a procession of Administration leaders appeared opposing both phases of the bill. ${ }^{102}$ On March 19 and 20, Robert Patterson, Under-Secretary of War, denounced the bill as not "practicable" and stated that the Excess Profits Tax was the only statute necessary for wartime profit limitation. ${ }^{103}$ On March 24, Donald Nelson claimed that the SmithVinson Bill was a faulty yardstick which would force contractors to demand the more expensive cost-plus-a-fixed-fee contracts. ${ }^{104} \mathrm{He}$ too favored the excess profits tax as the method to be used in recapturing excessive war profits. On March 25, Randolph Paul, representing the Treasury Department, strongly opposed the bill.108

The Administration seems to have opposed any rigid limitation of profits to a certain percentage of "cost" upon the belief that such yardsticks were not only cumbersome to administer, but they failed to achieve the objective of limiting war profits to reasonable amounts. In fact this plan seemed on the one hand to work hardships on companics with high capitalization thereby discouraging the production of war materials, and on the other hand it often allowed profits that were utterly excessive as in the case where a contractor had a huge annual gross and very small invested capital.

While Administration leaders were opposed to the passage of a uniform percentage limitation on war profits, they proposed no substitute. Congress, however, was interested in following Mr. Justice Black's suggestion of additional legislation to control war profits. ${ }^{100}$ One substitute was offered in the form of an amendment to the House Bill. This provided for the renegotiation of war contracts. ${ }^{107}$ This amendment never came to a vote for it was withdrawn, and on March

to1. H. R. 6790, 77th Cong., 2d Sess. (1942).

102. Wall Street J., March 21, 1942, p. 3.

103. Wall Street J., March 20, 1942, p. I.

104. IVall Street J., March 25, 1942, p. I.

105. Wall Street J., March 26, 1942, p. 4

In fact, other members of the Administration, including Navy Sccretary Knox, and Lt.-Gen. Somervell, did during April and May, 1942, oppose a flat limitation on profits.

106. 88 CoNG. Rec., April 2, 1942, at 3390.

107. 88 CoNG. REC., March 28 , 1942, at 3230. This clause provided: "Sec. 402-A. No part of any appropriation contained in this act shall be available to pay that portion of a contract for construction of any character and/or procurement of material and supplies. for either the Military or Naval Establishments, designated as 'final payment' until the contractor shall have filed with the procuring agency a certificate of costs and an agreement for renegotiation and reimbursement satisfactory to the Secretary of War or the Secretary of the Navy as the case may be" "(See also p. 3228.) 
28,1942 , by a vote of 70 to 8 , the House added to the Sixth Supplemental Defense Appropriations Bill a rider limiting profits on the fund subject to that bill to 6 per cent. of the cost of each contract ${ }^{108}$

In the Senate the Administration rallied its forces around Senator George, Chairman of the Senate Finance Committee, in opposing the House rider, but early in April it appeared that there were many senators who favored some additional limitation on war profits. This pressure in the Senate was so great that the Senate Finance Committee modified the house rider only to the extent that it limited the rate of profit to a lower per cent. of the cost on the larger contracts. ${ }^{100}$ The Administration leaders in the Senate, however, on April 6th, amended the bill on the Senate floor so that it authorized and directed the heads of the Navy, Army and Maritime Commission to renegotiate all contracts over $\$ 100,000$ in value where profits were or threatened to be "excessive"."10 The amendment also eliminated the Committee's 6 per cent limitation on war profits.

The Sixth National Defense Appropriations Act as finally passed directed the Arny, Navy and Maritime Commission to renegotiate existing and future contracts whenever in their opinion "excessive profits" have been or are likely to be realized. ${ }^{111}$ The statute provides in part:

s"The Secretary of each Department is authorized and directed, whenever in his opinion excessive profits have been realized, or are likely to be realized, from any contract with such Department or from any subcontract thereunder, (I) to require the contractor or subcontractor to renegotiate the contract price, (2) to withhold from the contractor or subcontractor any amount of the contract price which is found as a result of such renegotiation to represent excessive profits, and (3) in case any amount of the contract price found as a result of such renegotiation to represent excessive profits shall have been paid to the contractor or subcontractor, to recover such amount from such contractor."

It also provided that all future war contracts should have a clause permitting their renegotiation at any time.

From this legislative history it is difficult to determine whether the Administration really wanted to have this renegotiation procedure formalized by statute. It is true that the renegotiation of contracts was backed by the Administration, but it does not appear to have been

1as. SN CoNG. Rec., MFarch 28, 1942, at 3230-31.

109. \&N CosG. REC., April 6, 1942, at 3441-42

I10. SN Cosc. Rec, April 6. 1942, at 3441. See Sen. Taft's proposed renegotiation amen j-ent setting up a Profits Board composed of Secretaries of War, Navy and Treasury, Chairmen of Maritime Commission and W. P. B. \&S Cosc. REC, April G. 1942, at 344 R

ili. Pub. Law No. 528, 77th Cong; 2d Sess. (April 28, roq2) $\$ 403$ (b). 
a part of the regular legislative program of the Administration for the renegotiation clause was added to the Sixth Supplemental Appropriztion Act from the floor of the Senate in an obvious effort to forestall the passage of a 6 per cent. limitation upon war profits. The legislative chronology of the renegotiation clause clearly lends support to the view that the Administration drafted that clause only to forestall something which it censider:d to be less desirable.

At the time of the passage of the Renegotiation Act there was 2 clear implication that the enforcement of the renegotiation clause would not be too severe. This will undoubtedly be true as long as the primary objective of Administration leaders is to promote increased armament production and as long as they believe that the profit motive is the method most likely to further production. At the present tims the Administration does believe in a profit motive. This can readily be seen from an analysis of the endless testimony of the Administration representatives appearing before various Congressional Committees. This testimony discloses a tacit, but apparently strong, conviction that conversion from peacetime production to wartime production, that speedups and so forth can, on the whole, be best effected by increased, rather than decreased, economic inducement. In addition, Administration leaders have occasionally openly affirmed their belief in the necessity of the profit motive.

Since the passage of the Sixth Defense Appropriations Act, the various Price Adjustment Boards have been acting pursuant to its provisions. ${ }^{112}$. These Boards are now in the process of examining the profits of each of the thousands of firms holding a large volume of war contracts. To do its share of the work the War Department has set up numerous local sections throughout the country to act as the preliminary fact-finding boards. At present there appears to be a tendency among businessmen to wait and see how this new price adjustment machinery works. Businessmen are naturally reluctant to make voluntary reductions in their profits because of three quite natural fears. First, the fear of higher taxes, second, the fear of reductions in their income before taxes resulting from shortages of raw materials, and third, the fear that they will be unable to build up reserves to reconvert to peacetime production at the end of the war. Most businessmen feel that one of the costs of war business is the cost of reconverting from wartime production to peacetime pursuits and that consequently war profits must cover this cost. Up to now the Price Adjustment Boards have turned a deaf ear to this argument. 


\section{When Are Profits "Excessive"?}

Late in July, 1942, the Office of War Information announced that the experience of the Price Adjustment Boards demonstrated that the most practical approach to profit reduction was to study a company's overall financial position. ${ }^{113}$ Under this program an agreement on the amount of excessive profit is first reached, then it is translated into the company's contracts. When the House Naval Affairs Committee reported that the average profit on naval contracts was 8.1 per cent., the Committee took the position that such profits were not excessive. ${ }^{114}$ The Price Adjustment Boards, however, have never been willing to approve any specific percentage. Although these Boards have been renegotiating contracts for about six months and they have issued a joint statement of policy, ${ }^{115}$ it is impossible as yet to foretell what these Boards will deem to be "excessive profits."

One difficulty which necessarily arises from this renegotiation is the difficulty of determining what the statute means by "excessive profits". The term warrants some scrutiny. The Act gives no clue to its meaning. The term "excessive profits" seems to imply the existence somewhere of a level of profits which would be considered reasonable. Presumably the level of profits which would be reasonable would vary according to differing circumstances. This adds an item of uncertainty for each Price Adjustment Board to tackle.

From other statutes the term "excess profits" has come to have a definite meaning. Under these statutes it means profits which exceed a certain normal level. These statutes do not indicate, however, whether there is intended to be some correlation between a reasonable profit and a normal profit. Some light can be thrown on this question by considering what are normal profits and what are excess profits. Excess profits may in reality mean any of the following: First, the profits earned by a particular corporation in wartime which are in excess of normal, in the sense that they are more than what was earned by the same corporation in time of peace; second, the profits earned by a particular corporation represent a higher rate of return on capital during wartime than is common to this company in time of peace (this would be the same as the first unless new capital had been added); third, the profits earned by a particular corporation represent a higher rate of return on capital than is common to industry generally; and fourth, the profits earned by a particular corporation repre-

113. O. W. I. Release No. I63 (July 24, I942).

114 Report of House NAval Affairs Cosmuttee oN H. R. i62 (July 22, (1942) $\%$

115. O. W. I. Release No. 321 (August 19, 1942). See also War Dept. Principles, Policy and Procedure to be followed in Renegotiation (August 10, 1942). 
sent a higher rate of return than is generally believed to be a reasonable rate. Of course, under the fourth definition, an excess profit is probably also an excessive profit. Because normal profits may mean-sereral things, the term "excess profits" is not a definite one.

The most striking instance of excess profits would, of course, be excess in all four senses. Actually, the first and second criteria and the third and fourth criteria mark out distinctly different fields. The first two are taxed as excess profits by the present federal tax law. Actually they are $a \operatorname{tax}$ on war profits and not a tax on profits because they are unreasonably high. During the present war this country hasn't adopted any tax legislation based on either the third or fourth criteria. Such a tax would more properly be described as "high profits tax" instead of an "excess profits tax". While there is no tax statute on these bases, it would seem that the activities of the Price Adjustment Boards are really directed at reducing profits in line with the third and fourth criteria. If this conclusion is correct then these Boards are really imposing on industry a concept of what is reasonable profit. This, in effect, would place all industries engaged in war business in a class analogous to public utilities and would, undoubtedly, represent a step towards the socialization of such industries.

Aside from the problem of Government control of industry, there are a number of fundamental fallacies in a high profits tax which could be argued on purely legal, social and economic grounds. For example, such a tax, or action by the Board having the same result, neglects the fact that all taxes (and all reductions in profits) are ultimately paid by individuals and not by corporations, which are only legal entities. A $\operatorname{tax}$ on a corporation in reality amounts to a tax on its shareholders. A high profits tax on corporations discriminates between persons on a completely illogical basis. Of course, the graduated income tax discriminates between persons but on a basis that has come to be recognized as logical.

An economic and social argument could be made that it is not reasonable or fair to confiscate by heavy taxes the wealth of corporations without thinking of what this implies to its shareholders. Under these circumstances it seems that the principle of taxing war profits is a more equitable solution to the excess profits problem than the taxing of high profits.

If the foregoing analysis is correct, the concept of "excessive profits" is related to a high profits tax on corporations. If such a tax is unfair and discriminatory then in reality the concept of excessive profits contained in the Contract Renegotiation Statute ${ }^{110}$ has no rela-

116. Pub. Law No. 528, 77th Cong, 2d Sess. (April 28, 1942) $\$ 403$ (b). 
tion to the problem of excess war profits but is connected primarily with the abstract concept of what profit a particular corporation is entitled to earn. A grave legal question is raised by the delegation by Congress of the determination of what constitutes an excessive profit to any Board without any standards set to assist them in their determination. Without such definite limits or standards, the rationale used by the Supreme Court in the Panama Refining Co ${ }^{117}$ case in holding the delegation of authority unconstitutional would seem to be applicable here. Such an abdication of an essential legislative function could hardly be justified by the fact that the renegotiation of war contracts is closely connected to the carrying on of war. In addition, the reasoning of the Supreme Court in holding the Anti-inflation Act of World War I unconstitutional ${ }^{118}$ because the statute failed to set up a sufficiently definite standard, would seem to equally be applicable to this statute.

Another effect of this compulsory renegotiation is to make a contract with the United States an obligation binding on both parties only when it happens to result in disadvantage to the private contractor. It makes the same contract null and void when it operates to the contractor's advantage. It is difficult in such a situation to find the mutuality of obligation which is a fundamental concept in the law of contract. Other questions as to the legality of this statute are raised by the attempts to have it govern prior contracts, thereby apparently depriving the contractor of property without due process of law.

There are other points on which this Renegotiation Act can be criticized. One distressing feature of renegotiation is that it may actually penalize a company which has co-operated Ioo per cent. by converting to war work. Take for example the hypothetical case of two manufacturers making the same item. After the war starts, $A$ converts to war work selling all his production to the Government and $B$ takes over the commercial trade. $A$ is subject to renegotiation, while $B$ is not. Such a result hardly encourages companies to continue to forego peacetime business if they are not prevented by priorities. Under these circumstances renegotiation would hardly be an incentive to increased war production. Another criticism that could be leveled at this Act is that it provides for no court review from the Assistant Secretary of War's ruling.

\section{The Future of Renegotiation}

The Renegotiation procedure is perhaps not with us to stay. Senators George, Vandenburg and Danaher have flirted with the idea 
of having this Act amended or repcaled. ${ }^{110}$ The hearings before the Senate Finance Committee on the Revenue Act of 1942 provided an opportunity for many suggestions concerning renegotiation. Senator George proposed to supplant this procedure by a percentage limitation on war profits. ${ }^{120}$ This proposal was based on the theory that the profit on war contracts should be subject to only two taxes, the first the corporate income tax, and the second a tax which would take from each corporation all profits in excess of 5 per cent. of the gross volume of the contract prices on fixed-price contracts and I per cent. on goods produced on Government-owned facilities. In order to protect the producer he was to be allowed to offset losses in one year against profits in another year, then at the end of the war a final accounting is to be heid. After this accounting the producer is to pay over to the Government all profits in excess of 5 per cent. on the fixed-price contracts and I per cent. on management-fee contracts for the whole war period. If he hasn't earned that much his taxes are to be refunded by the Government in sufficient amount to equal this amount of earnings. This suggestion and the question of repealing the Act were referred on September 22, 1942, to a special sub-committee with Senator Walsh as Chairman. On September 29, 1942, Assistant Secretary of War Patterson appeared before this sub-committce in favor of the renogotiation procedure. ${ }^{121}$ This sub-committee was originally to report before the Senate had finally passed the Revenue Act so that it could be made an amendment to that Bill if it was thought desirable. ${ }^{122}$

Subsequently it was decided to postpone any major amendment to the renegotiation statute as a part of the Revenue Act. As a result none of these proposals were ever reported out by this sub-committce.

As a result of all this discussion of renegotiation two significant amendments were made by the Revenue Act. ${ }^{123}$ One authorized the Price Adjustment Boards to enter into a final agreement settling a company's profits. Such agreement cannot be opened up except upon a showing of "fraud or malfeasance or a wilful misrepresentation of a material fact". This was a concession to industry's desire for certainty. The other clarified the inter-relation of the tax laws and refunds resulting from renegotiation. Various other proposals for amending the renegotiation procedure have been made. ${ }^{124}$ The. most important

119. Wall Street J, August 7, 1942, p. 3.

120. N. Y. Sun, Sept. 12, 1942, p. I; N. Y. Times, Sept. 15, 1942, p. 22; N. Y. Times, Sept. 16, 1942, p. 35; Wall Street J., Oct. 1, 1942, p. 4

121. N. Y. Woild Telegram, Sept. 29, 1942, p. 24

122. Prentice-Hall; Government Contracts, $\Upsilon \mathbf{3 9 . 8}$

123. Revenue Act of $1942, \S \S 80,3806$.

124. Cf. Flynn, Cost-Plus and Red Tape Hamper War Production, Barron's Magzzine, Aug. 3I, I942. 
of these involves the suggestion that the range of profits that may be allowed in renegotiation proceedings should be given definite percentage limits.

It is undoubtedly too early to pass final judgment on the renegotiation procedure, but at least four things are now clear. It requires a great deal of additional accounting. Unless the Price Adjustment Boards are willing to enter into final agreements in all instances it places businessmen in the position of never knowing when their books are closed and when a "profit" is actually theirs. It forces men needed for war production to devote their time to checking over cost and profit figures and to answering the questions of the Price Adjustment Boards. Perhaps most serious is the fact that to the extent that these Boards are using the percentage of profit to the gross volume of business as a yardstick they are in effect reinstating the cost-plus-a-percentage-of-cost system of determining profits. This system was discredited in World War I, because it not only did not contain an incentive to reduce costs, but the only incentive present operated to increase costs as much as possible. ${ }^{123}$

Certainly an end of renegotiation would accomplish two results. It would terminate the lengthy renegotiations and it would let businessmen know just where they stand. The latter is important for though businessmen are naturally interested in profits, it is equally true that they are interested in certainty. As a class they want to know where they stand and to have a fair opportunity to forecast the future. Laws or procedures which upset business certainly are bound to have a bad effect upon relations between Government and industry. The amendment authorizing a Price Adjustment Board to give a final certificate subject to being reopened by the Assistant Secretary in only unusual circumstances such as fraud or wilful misrepresentation of fact goes a long way to solve this problem.

The Administration, however, does not rely solely on the renegotiation of war contracts in order to control war profits. It also relies on a high excess profits tax. This program undoubtedly would adequately protect the Government against profiteering if renegotiations were applied ruthlessly and without regard to the survival of American business. Certainly no one contests the fact that war profits must be controlled. It is the methods which are all important. The work of the Truman and Vincent Committees and the Price Adjustment Boards clearly raises the question of whether the methods employed in the United States have been as satisfactory as could have been devised. An examination of the way in which the Dominion of Canada had handled 
this problem sheds considerable light on how this control might have been made more satisfactory both to Government and to industry.

\section{Canada's Prograim for Controlling War Profits}

Canada has avoided getting involved in the question of "excessive profits" by the simple expediency of planning their purchasing of munitions and war supplies in a way which generally prevent high profits from arising, and which encourages reductions in cost to the Government. ${ }^{120}$ The tax laws are then relied upon to do the rest.

As the Dominion of Canada began to equip a modern army and to aid the mother country, it faced the same procurement problems as were later faced by the United States. There was the need for encouraging a rapid conversion from peacetime to wartime production. There was a realization that war profits had to be controlled. But that is where the similarity ceases. In the first place the internal situation in Canada was more conducive to harmonious co-operation between the government-and industry. This rests on four facts. First, business in Canada had no hangover of hate or distrust such as existed in some quarters of the United States as a result of the New Deal; second, there are so few producers in Canada that the Department of Munitions and Supply is familiar with each company, and can deal with them on a personal basis; third, labor was willing to forego using the war as a means of soldifying or improving its position, and there was an absence of jurisdictional disputes between labor groups; fourth, all prices were rigidly fixed as of December I, I94I. (Prior to that, all contracts had escalator clauses which caused considerable trouble.) Each of these factors has profoundly affected the problem in Canada by simplifying the procurement of munitions and war supplies.

Although His Majesty's Government for the Dominion of Canada was opposed to allowing profits to be made out of the war effort, it concluded that the profit motive was so ingrained in the Canadian way of life that the conversion to war production and the reaching of maximum production could best be secured by allowing some profit to be made. Its program was based on the premise that business was entitled to a profit in converting its plants to war work. This profit, however, was to be a small one and generally without regard to the needs of the company after the war. Having reached this decision, the Department of Munitions and Supply for the Dominion of Canada was charged with devising contracts which would insure this result. From the very

126. The author is indebted to Mr. W. J. Bennett, Exccutive Assistant to the Minister of Munitions and Supply, and to his associates, for information relative to the policies and practices of the Dominion of Canada on war contracts. 
outset it adopted a program for procuring war supplies which seems to have resulted in low prices to the Government and fair profits to the manufacturers. In carrying out the Canadian Governmental policy, the Department of Munitions and Supply studied many types of contracts. As a result of this study the Department decided that both "cost-plus-a-fixed-fee" and "cost-plus-percentage-fee" contracts should be used only in rare circumstances because they are extravagant and result in high total cost to the Government. As another result of this study a series of contracts were worked out to cover all of the various situations.

The contracts which Canada has relied upon as safeguards against "excessive" profits have differed, depending on the type of the commodity being purchased. Regardless of the commodity being purchased the original contract with each producer is carefully negotiated on the basis of a careful study of costs of producing the particular commodity in Canada and England. Only short-term contracts, rarely running more than six months, are entered into. Government accountants are constantly auditing costs on each large contract and contracts are only renewed on the basis of the cost experience on the previous contract. In addition, whenever possible, contracts are drawn so as to leave some incentive to the manufacturer for the reduction of costs. By following this program, the Canadian Government has found that costs to it have been kept down and "excessive" profits have resulted in very, very few instances.

There is no Canadian Law or Order in Council which permits or provides for a renegotiation of contract prices or fees. Since each contract has only a few month' duration, even a situation where "excessive" profits might result could readily be cured without having to set up such elaborate machinery as the Price Adjustment Boards which have been set up in the United States. That does not mean, however, that prices and fees have not been renegotiated or reduced. What it does mean is that there is no board for adjusting prices whose success may be judged by the millions of dollars that industry is induced to turn back. In a few cases, the Department of Munitions and Supply has called in manufacturers and suggested reductions. In practically every instance reductions have resulted. Whenever there is a failure to reduce the price, it is taken into consideration in awarding the next contract.

Most Canadian war contracts cover the purchase of items of which there was a shortage in that Dominion. From the beginning of the War, the Department of Munitions and Supply has promoted the conversion of plants and their machinery to war uses rather than the con- 
struction of new plants which would require the purchase and manufacture of new machines and machine tools. This was a virtual necessity because of the very small machinery and machine tool industry in Canada and of the high cost of importing machinery and tools from the United States. Despite this policy, well over 50 per cent of Canada's war production is carried on in newly-constructed governmentowned plants.

\section{Canada's War Time Procurement Methods}

Even during the war, Canada purchases some commodities which were important in Canada's peacetime economy. There is generally a surplus capacity to produce these products. This group includes most agricultural commodities and a few manufactured products such as lumber and cement. In the purchase of these commodities Canada follows its peacetime practice of sending out invitations to bid. The award is then made to the lowest responsible bidder, unless in the opinion of the purchasing agent the price is too high. If it is thought to be too high, the bids are thrown out and a readvertisement takes place.

Canadian procurement by securing competitive bids is more elastic than in the United States. The Department of Munitions and Supply does not have to accept the lowest bid if it doubts the ability of the bidder to meet all the conditions of the bid or if it wastes foreign exchange. In addition, the Department may, and often does, bargain with the bidders. ${ }^{227}$

In some instances these bids have been identical. Like most procurement agencies, the Department of Munitions and Supply has assumed both that the bids were arrived at by collusion and that the prices were too high. When identical bids are received and if they are not unreasonably high, the award is split equally between bidders at the bid price, but each contract contains two very significant clauses. The first clause provides for an audit of production costs and the second reserves to the Minister of Munitions and Supply the right to reduce the contract price so that the manufacturer receives only a fair and reasonable profit. During wartime, the reasonable profit is usually considered to be around 5 per cent. of the cost of manufacture. The exact percentage of profit allowed depends somewhat on the commodity involved and the length of time it takes to produce it. There have been a few instances where a Canadian manufacturer has refused a contract with these two clauses. Under these circumstances the awards are made to the other identical bidders.

127. Preliminary Report of House N'azal AfGairs Committee pursuant to H. R. Ibz (Jan. 20, 1942) 113 . 
In purchasing commodities of which there is a shortage in Canada sealed bids are not used. Different types of contracts are used in handling this situation. The purchase of large quantities of small items or of fungible goods is probably the best illustration of Canada's technique in reducing prices and eliminating the possibility of "excessive" profits. When it came to the first purchases of a large quantity of small items, the Department of Munitions and Supply chose those companies whose facilities could most economically be converted to the manufacture of each item. Each of these companies was asked to submit its estimated cost of producing a given quantity including the conversion of its facilities so that it would, on the completion of the order, have 2 certain daily capacity. Each manufacturer would bring in his costs and they would be discussed with him, and then compared with the English cost figures. Usually the costs would be pared down a bit and finally a number of the manufacturers would be chosen to produce the item. As this might take time a few of the manufacturers were usually asked or directed to proceed to manufacture the commodity long before the contract was worked out.

The first contract for the purchase of these types of commodities was alu'ay's a target contract. These contracts provided for a fixed estimated cost per unit. The contract then provided for a fixed amount of profit which usually was 5 per cent. Under the target contract, if the cost ran over the agreed-upon estimated cost, then 25 per cent. of this excess was taken out of the agreed-upon profit provided that in any case 3 per cent. profit was to remain to the producer. If the actual cost was less than the agreed-upon estimated cost, then 25 per cent. of this saving went to the manufacturer.

These target contracts were designed for two purposes: first, to encourage the manufacturer to make the conversion to war production as cheaply as possible, and second, to serve as a trial run which could be used as a costing study. Throughout the operation of this first contract the mantfacturer's cost was carefully supervised by government accountants. One way the cost was kept down on the first contract was for the Department of Munitions and Supply to purchase and supply the additional equipment needed to convert the plant. This kept competing manufacturers from bidding up the price when trying to get equipment.

When the time came to enter into a second contract the manufacturer was in production and had some definite cost experience. As a result, in all but a few instances, this second contract provided for a fixed price based on the experierice gained from the target contract. (In a few cases, however, a new target contract was necessary.) The 
fixed price was usually based upon the estimated cost plus 5 per cent. profit. As this was a fixed price contract it tended to encourage the manufacturer to increase his capacity, to take short cuts, and to make all the savings possible. Each of these increased his profits. At the end of this contract (which originally was to have taken six months but was probably completed in less) a third contract was entered into which takes into consideration the plant capacity, and the cost picture at the close of the second contract plus profit equal to 5 per cent. of cost. This third contract is still on a fixed price basis, as will be the fourth, fifth, and so on. As a result the price will be a steadily descending figure providing specifications are not changed and the costs of labor and materials do not go up.

There are many amazing results from this program. For example, the original target contract for a certain part of a shell specified a cost of $\$ 6.5^{\circ}$ plus a profit of about 30 cents. Subsequent fixed price contracts have successively reduced the price until it is a mere 67 cents. In this case the manufacturer is actually making a larger total profit now than on the original contract. This has resulted from increased volume and from improvements reducing costs by using new type machinery and new processes and by the substitution of cheaper materials.

It will be readily appreciated that under both the target and fixedprice contracts a company going into a new line of endeavor under war contracts will probably receive higher fees per unit of production than a company already in the business. This is inevitable under the target contract scheme. As the new company, however, acquires the "knowhow" during the life of successive contracts its profits and fees per unit would normally come into line.

The Department of Munitions and Supply from its consideration of the problem concluded that the purchase of many large items could not be covered by a single type of contract. Therefore in the purchase of small quantities of various large types of military equipment a number of contract forms were devised to meet each special situation.

The most important type of such contract is called the "Ceiling Price Contract". This contract sets a ceiling price for the commodity which is arrived at generally on estimated costs after a careful comparison with British and Canadian industrial experience. The price ceiling also includes a profit which is figured on a percentage of these estimated costs. This precentage is usually 5 per cent. The contract, however, calls for an audit of cost and the profit is limited to 5 per cent. of the total cost of production. If the cost including the manufacturer's profits exceeds the ceiling price, the manufacturer is only reimbursed up to the ceiling price. $\because$ : 
The Department of Munitions and Supply have recognized that under this type of contract there is no immediate monetary incentive for the manufacturer to reduce costs. In spite of this fact the experience in Canada has been that nearly all companies have repeatedly reduced costs in operating under these contracts. Some incentive results from the fact that if a manufacturer makes savings, some way is found to give him a part of the benefit in the next contract. The Department of Munitions and Supply has a representative, who is familiar with production and who makes suggestions as to cost savings, in factories operating on this basis. Although there is no power which can compel a manufacturer to adopt these suggestions (short of a threat to cancel the contract), his cooperation is one of the factors considered at the time of negotiating a new contract.

Another type of contract to cover small volume purchases covers the purchase of boats. Usually the boat contracts are awarded after sealed bids. The award goes to the lowest bidder if the bid price is not excessive. If more than one boat is involved, other bidders are allowed to meet the low bidder. This, of course, reduces the incentive to quote your lowest price in the first instance. After the awards are made a special type of contract is entered into. This contract has a price ceiling and then contains an itemized list of the major costs such as the motor, the steel, etc. If, for example, the ship's motor is estimated to cost $\$ 90,000$ and it is purchased for $\$ 85,000$, then the price ceiling is reduced by $\$ 5,000$. There is no incentive in these contracts for the manufacturer to make such savings, but the Canadian Government assists in the purchase of the major items. The Department feels that this procedure has accomplished the same result as incentive to the manufacturer.

A second type of contract for small quantities of large items is the cost-plus-a-fixed-fee contract. The fees run from 3 per cent. to 5 per cent. of the estimated costs. These contracts are relatively unimportant as less than 2 per cent. of all the war contracts are of this type and they cover less than I per cent. in dollar value of purchase. One important difference in Canada in considering the estimated cost in fixing the fee is that cost is not interpreted to include the cost of items furnished by the Government. In Canada this is specially significant, for the Government manufactures many of the basic commodities used in manufacturing military supplies and munitions and furnishes them free of charge to all producers operating under Government contracts.

The cost-plus-a-percentage fee contract is used in a few Canadian contracts. It is used only to purchase replacement or spare parts which vary in quantity or specification. In this case, too, the cost includes 
only the cost reimbursable to the producer and, like the other type of cost-plus contract, cost does not include the cost of items furnished by the Government and the fee is invariably 5 per cent.

The final contract type results from the fact that much of Canada's production has had to be carried on in new plants constructed and owned by the Government. Virtually all of these Government-owned plants are operated by companies on management fee contracts. This fee runs from a nominal amount to 3 per cent. of the estimated reimbursable cost of production. In all of these plants there are present not only accountants but also trained Government production engineers who check savings and costs. These contracts, nevertheless, make it clear that the "Contractors shall have control over and be responsible for the operation of the plant and the conduct of the work". 128 In most contracts there is a provision which gives to the manufacturer 2 part of any saving in cost which he makes.

Because of the large percentage of Government-owned plants among the new war plants, the management fee contract is the most important type of Canadian contract. Actually from 50 to 60 per cent. of all war production is manufactured under this type. Unlike the situation as to many new plants in the United States, the Government in Canada will continue to own these new plants after the war except in the relatively few cases where for production reasons a new building is constructed in the center of an existing commercial plant. In those cases the company has the right of first refusal of any bona fide bid price for the building with or without facilities.

There are certain provisions which are common to virtually all of the Canadian war contracts. Thus, just as in the United States, each of these contracts normally has a provision permitting the Minister of Munitions and Supply to terminate or suspend a contract at will, with or without cause. Upon such termination every effort has been made to protect the producer for all expenditures made or obligations assumed in good faith for performance of the contract prior to the date of its termination. For example, His Majesty's Government must reimburse the manufacturer for all direct expenses (including capital expenditures) to the extent that they were reasonably and properly incurred in the performance of the contract. The inventories of raw materials at termination are, if accumulated in good faith, proper costs chargeable to the Government, except on some fixed-price contracts. In all but these fixed-price contracts this problem does not arise because all other contracts vest the title to all "materials and supplies acquired by or in the possession of the contractor for the purposes of the work

128. M. \& S. Contract Form No. 1206. 
in His Majesty".120 The contractor is then made liable only for loss of these materials and supplies resulting from "gross negligence or wilful misconduct."

In the fixed-price contracts some relief from possible losses on expanded inventories is given under the Tax Laws. Under these contracts, a manufacturer is permitted to set up an inventory reserve covering the normal quantity of inventory which he would have on hand during a standard period which is usually decided to be the average of the years 1936 to 1939 . The amount of this reserve is measured by the difference in the current value of the inventory as compared with the value of the inventory in the standard period. This amounts only to partial protection in view of the fact that most companies have had to expand their inventories in order to meet their war contracts and no provision is made for any expansion in the size of the necessary inventories. Canadian companies have been able to work out exceptions to this rule by means of special provisions in their war contracts. For example, under one such provision the Canadian Government has obligated itself to purchase the entire output of the plant for six months following the cessation of hostilities.

If a contract is temporarily suspended, the contractor is not entitled to any compensation for any loss of anticipated profits-or-fees as a result of a suspension of or decrease in the work called for by such a contract. This same result applies if the contract is terminated, unless it is established to the satisfaction of the Minister of Munitions and Supply, that by reason of such action exceptional hardship has resulted to the contractor. In those cases the Minister may, in his absolute discretion, grant a proper allowance under the circumstances. The allowance may not, however, compensate for any loss of profit.

The Department of Munitions and Supply has also set up an Appeals Committee in the Department to which any manufacturer can appeal any decision against him resulting from the negotiation or operation of the contract. A contractor has the further right of appeal to the Minister but in practice the Minister virtually always sustains the Department and its Appeals Committee.

While this is the basic procedure of the Department of Munitions and Supply, there are variations to meet special cases; in addition, there have been a few recent changes in policy. The newest development in the contract procedure is a contract calling for an auditing of all the books and accounts of the company covering all the operations under their war contracts for a period of cne year or six months. The advantage of such a contract to a producer is that it eliminates losses from a 
single contract. So far a number of companies have entered into these contracts, which, in effect, amount to a fixing of a specific fee to cover all of a company's business for an entire year regardless of the original contract price or fees involved. This contract produces a result similar to the Vinson Act as amended in $1936 . .^{180}$

These audit contracts provided that if the annual audit established that the total profit occurring to the contractor in respect to a given year's business is in excess of a sum equal to a definite percentage of the cost of that part of the business "pertaining to manufacture" of the product in the manufacturer's plant and to a lower percentage of the cost of that part of the business pertaining to munitions of war and war supplies manufactured in Government-owned plants, the contractor shall credit the amount of such excess to the Dominion Government. These annual audit contracts are somewhat similar to a renegotiation of war contracts. The adoption of an annual audit contract, however, is purely voluntary and the percentage of profit is determined by open negotiation before the contracts are completed.

A pending development in procurement procedure in Canada is the proposal to put all of the standard contractual provisions concerning costs, termination, responsibility for claims and other general provisions in one document and have it issued as an Order in Council. It is expected that an order to this effect will be issued some time soon. Such an Order would have the effect of taking a large number of standard terms out of the field of provisions which can be negotiated and they would be binding equally on all contractors.

\section{What Is Cost?}

Under both the Canadian and the American contract controls the meaning of the word "cost" is very important. In this country the War and Navy Departments in 1942 collaborated on a booklet explaining this subject. ${ }^{181}$ The Canadian Department of Munitions and Supply has issued a Costing Memorandum. ${ }^{132}$ This Costing Mcmorandum was incorporated by reference in all Canadian war contracts from the start of its program.

Generally speaking, there is considerable agreement on costing principles used by the War and Navy Departments and Canada's Department of Munitions and Supply. In Canada cost is meant to in-

I30. 49 Stat. 1926 (1936), 34 U. S. C. A. $\$ 496$ (Supp. 1941).

131. Explanation of Principles for Determination of Costs under GovererLENT CONTRACTS (I942).

132. The items which are recognized as..part of cost are set forth in a Costing Memorandum of the Department of Munitions and Supply entitled "Costing Memorandum, M. \& S. $433^{\prime \prime}$. 
clude expenditures made by the contractor in performing the contract, and is the sum of direct material and direct labor and a proper proportion of applicable indirect costs (including a reasonable proportion of management expenses). In order to clarify the meaning of "cost" the Canadian Memorandum excludes eighteen specific items. ${ }^{133}$

Many of the problems which arise in the United States in dealing with the War or Navy Departments do not arise in Canada because the Department of Munitions and Supply uses the same principles concerning allowable costs as are used by the Department of National Revenue and the Commissioner of Income Tax. The only differences result from adjustments which must be made in determining costs under a single contract as compared with costs for an entire year's business. In Canada another guarantee of similar treatment of costs results from the fact that accountants used to supervise the war contracts for the Department of MIunitions and Supply come from the Income Tax Office.

It is impossible in the scope of this article to make a detailed comparison of the Canadian Costing Memorandum and the U. S. Army and Navy booklet. Both of these documents are so broad in scope as to require numerous interpretations in their application. There are, however, one or two important differences. The Army and Navy Booklet lists expenses due to strike and lockouts as non-reimbursable. The Canadian practice is to allow such costs. The American Booklet lists as non-reimbursable special legal fees for patent infringement cases. The Canadian Costing Memorandum makes no mention of such lawsuits, but the practice is to allow such costs if they are incurred in good faith.

133. The following items are expressly excluded by M. \& S. 433:

(1) Allowances for interest on invested capital, bonds, debentures, bank or other loans.

(2) Entertainment expenses. -

(3) Dues and other memberships other than regular trade associations.

(4) Donations (except as stated in Section 3, Subsection (b) hereunder).

(5) Losses on other contracts.

(6) Losses from sale or exchange of capital assets.

(7) Depreciation on buildings, machinery or equipment paid for by the Crown.

(8) Fines and penalties.

(9) Amortization of unrealized appreciation of values of assets.

(10) Expenses, maintenance and/or depreciation of excess facilities.

(II) Increases in reserves for contingencies, repairs, compensation insurance and guaranteed work.

(12) Federal and Provincial income, excess profits or surtaxes.

(13) Unreasonable compensation for officers and employees.

(14) Bond discount or finance charges.

(15) Premiums for life insurance on the lives of officers.

(16) Legal and accounting fees in connection with reorganizations, security issues, or capital stock issues.

(17) Losses on investments, bad debts and expenses of collection.

(18) Advertising and selling expenses. 
Another interesting and important subject is salaries and bonuses. High salaries and bonuses are not reimbursable costs under the Army and Navy Department cost statement. In Canada they are not listed as being among the items which will not be reimbursed by the Canadian Costing Memorandum. There has been a long-established practice, however, in Canada for the Income Tax Commissioner strictly to prohibit as allowable corporate tax cost deductions large increases in salaries or bonuses. As a result, there has been a tendency in Canada for them to be kept at a low level. Actually any salaries or bonuses approved by the Income Tax Bureau are reimbursable costs on war contracts.

There is an interesting omission in the Canadian Costing Memorandum of any reference to conversion to war production or reconversion to peacetime pursuits. In practice the costs of conversion to war use are invariably reimbursed as a part of the cost of the first contract. Absolutely no provision has been made for the reconversion to peaceful pursuits by either the Department of Munitions and Supply Costing Memorandum or under the Canadian Tax Laws. As a matter of fact up to the present time there has been no applications to the Department of Munitions and Supply or the Bureau of National Revenue for the approval of such reserves as costs. This then is a problem which both Canadian industry and Government must face at some future time.

All in all the Canadian Costing Memorandum seems fairer and more liberal to the manufacturer than the American Booklet. In addition its announcement at the commencement of the war program and its administration by the Bureau of National Revenue tend to give a certainty to the program not present under the United States program where costs are determined by three separate agencies for the purpose of the tax laws, to reimburse expenditures and in the renegotiation of contracts.

One disadvantage of the Canadian system is that the determination of allowable costs under the Canadian contracts is more complicated than under the American cost-plus-a-fixed-fee contracts. This arises from the fact that in Canada cost includes a large number of indirect factory and miscellaneous expenses. As a result, after costs are submitted by the Canadian producer they are gone over by an Income Tax accountant and certified to the Director of Munitions and Supply. If the manufacturer disagrees with them as certified, he can appeal to the Director and subsequently to the Appeals Committee and finally to the Minister. Government officials in Canada have not hesitated to state that they have carefully examined claims for reimbursement of indirect costs made by any producer if there was any reason to suspect any dishonesty or lack of good faith. 


\section{Canadian Tax Laws}

In Canada the tax laws are an integral part of the control of war profits. At the outset of its war program the Canadian Government believed that confiscatory "excess profits" taxes would result in discouraging conversion to war production and would result in a reduction in the incentive to keep down costs. As a result the original Canadian Excess Profits Tax was deliberately kept below Canada's financial needs. Now that the conversion to war production has been virtually completed and the steps taken to keep down costs have proven successful, a new tax is before Parliament. This law proposes much higher rates of excess profits taxes. ${ }^{184}$

In considering the tax laws of the Dominion of Canada it should be remembered that it has largely inherited its fiscal traditions from Great Britain. The main difference between the two tax structures is that Canada has always placed, both in peace and in war, a greater reliance on indirect taxes. The main difference between Canadian Tax laws and United States Tax laws is that the Canadian laws set down broad general principles and considerable latitude is given to the Commissioner in applying them. As a result Canada has neither the detailed provisions in its Revenue Acts nor the mass of regulations that the United States has.

The June, 1940, war budget contained the First War Tax Law. That Act for an 18 per cent. normal corporate tax and a War Profits Tax of 12 per cent. of the total net profit or of 75 per cent. of all net income earned over the 1936-39 average income, whichever were the greater. ${ }^{135}$ While this 75 per cent. maximum seems large, the Commissioner was given broad discretion to give relief from its operation. ${ }^{138}$

This Excess Profits Tax differed from the United States Excess Profits Tax in that it had no invested capital option. This Canadian Tax was considerably broader in scope than Canada's World War I Tax. It applies to all business and trade carried on in Canada whether incorporated or not. Thus it applies to farmers' excess profits. It does not, however, apply to incomes from certain professional occupations.

134. 92 Canadian House of Commons Debates 3901 (June 23, 1942). In his Budget Message Mínister of Finance, J. L. Ilsley stated: "The time has now come when we can and should make the excess profits tax more severe. The rate of expansion in business will now be much less than it has been heretofore. In the case of many civilian businesses the volume of their production or turnover is likely to decline rather than expand. Even in the field of war production we are getting close to the levels of full capacity. Consequently, businesses in general no longer need to retain substantial amounts of their current profits for reinvestment in working capital and can afford to pay a large proportion to the treasury." (1940)

135. Dept. of National Revenue, Excess Profits Tax, Explanatory Brochure

136. Dept. of National Revenue, Excess Profits Instruction Form S. P.-r. 
This 1940 Tax Act set up another important part of the Canadian tax structure, i. e., the War Depreciation Board. Unlike the cumbersome provisions for amortization of war plants and facilities extant under the United States Tax laws the Canadian Tax Act gives this Board a wide discretion to solve particular problems. This Board regulates the deductions for depreciation or amortization of plant or equipment built or purchased to fulfill war contracts, for the purposes of both the Income and Excess Profits taxes.

This problem usually arises from the fact that some companies have preferred to finance their own plant additions. Obviously, a building costing $\$ 500,000$ may have a peacetime value of only $\$ 200,000$ to the manufacturer. It was to grant relief in such cases that the War Depreciation Board was set up. This Board determines what the value of the building will be to the producer after the war, and provides for its depreciation to that level. In practice, Canadian industry has found that this Board has been very liberal in its depreciation allowances; in fact, a manufacturer is usually allowed to write his own ticket as to the length of this period. For some reason most producers have selected a three year period.

The 1940 Tax Act also provides for a Board of Referees to set up appropriate standards for new firms and to make arrangements for firms or industries whose income was unduly depressed in the standard period or companies whose capital is being impaired. ${ }^{185}$ Subsequent Tax acts have continued this Board. In submitting its claims the company can use any standard of comparison which it feels it can support.

In 1941 the Canadian Tax Law was amended. The 18 per cent. normal corporation profits tax was retained but the excess profits tax was to be 22 per cent. of the total profits, or 75 per cent. of the profits in excess of the average standard profits whichever were greater. This means that all companies had to pay in $194 \mathrm{I}$ at least 40 per cent. of total profits ( 18 per cent. normal tax and 22 per cent. excess profits $\operatorname{tax}$ ).

At the present time the 1942 Tax Bill is before the Canadian Parliament. 138 This bill provides for a corporate tax of 30 per cent. on all profits and an excess profits tax of ro per cent. of all profits, or of 100 per cent. on all profits in excess of the average for the standard period, whichever tax is greater. Under this r942 Tax Bill a company would pay as under the I94I Act at least 40 per cent. of total profits as a corporation tax. Accompanying this increase in excess profits tax (1940)

137. Dept of National Revenue, Excess Profits Tax Explanatory Brochure

138. 92 Canadian House of Commons Debates 3912 (June 23, 1942). 
there is a provision that 20 per cent. of the excess profits tax paid under the 100 per cent. tax is refundable without interest after the war. It does not apply to the amount of excess profits tax paid under the ro per cent. provision. The refundable portion of the tax paid for income received in 1942 will be refunded not later than the end of the second fiscal period commencing after the cessation of hostilities, and for 1943 not later than the end of the third fiscal period.

\section{Conclusion}

Canada's method of controlling war profits is to negotiate contracts carefully and for a short period of time and to provide whereever possible an incentive to the manufacturer to reduce his costs. The $\operatorname{tax}$ laws are left to take care of the rest. No provision has been made for the control of war profits by the renegotiation of war contracts. Actually, the Canadian Government feels that renegotiation machinery is unnecessary in view of its experience during three years of war.

The Canadian program seems to have eliminated practically all excessive profits. At the same time it has encouraged producers to increase capacity and make savings in costs of manufacture thereby reducing the cost of Canada's war effort. Actually it seems to have done away with the necessity of renegotiating war contracts and all the accompanying difficulties such a program entails. To these results might be added another, namely, Canadian industry has a feeling of certainty that seems to have resulted in virtually complete cooperation for the purpose of winning the war.

Undoubtedly there are lessons for the United States to learn from Canada's experience. Before any further steps to restrict profits are taken, it would be well to remember that some forms of controlling war profits will result and have resulted in waste, and consequently have hampered the war effort. Perhaps the most effective way of controlling the cost of waging the war would be the careful control of expenditures. The experience of this country in the last war was that the numerous methods developed to control peacetime procurement are virtually unworkable when the premium is upon securing peak production. Perhaps there is no single solution to this problem, but certainly a successful system will make use of every method to keep down costs which does not interfere with the battle of production.

Some recognition of the advantages of the Canadian system of controlling war profits by the target system of readjusting war contracts came when the War and Navy Departments presented to the Senate Finance Committee a proposal on September 28, 1942, that the 
Renegotiation Statute be amended so that they are given clear authority to invoke this method of controlling war profits. ${ }^{139}$ Certainly Canada's policy on awarding war contracts for short terms and subject to continuous scientific cost inspection and thereafter relying on high corporate and excess profits taxes seems better adapted to eliminate war profits without any discouragement of production than the procedures which have been followed in the United States.

139. Wall Street J., September 29, 1942, p. 3. 